\title{
Selection and dissemination of antimicrobial resistance in Agri-food production
}

\author{
Guyue Cheng ${ }^{1 * \dagger}$, Jianan Ning ${ }^{1 \dagger}$, Saeed Ahmed ${ }^{1}$, Junhong Huang ${ }^{1}$, Rizwan Ullah³ ${ }^{3}$ Boyu An ${ }^{1}$, Haihong Hao', \\ Menghong Dai', Lingli Huang ${ }^{2}$, Xu Wang $^{1}$ and Zonghui Yuan ${ }^{1,2}$
}

\begin{abstract}
Public unrest about the use of antimicrobial agents in farming practice is the leading cause of increasing and the emergences of Multi-drug Resistant Bacteria that have placed pressure on the agri-food industry to act. The usage of antimicrobials in food and agriculture have direct or indirect effects on the development of Antimicrobial resistance (AMR) by bacteria associated with animals and plants which may enter the food chain through consumption of meat, fish, vegetables or some other food sources. In addition to antimicrobials, recent reports have shown that AMR is associated with tolerance to heavy metals existing naturally or used in agri-food production. Besides, biocides including disinfectants, antiseptics and preservatives which are widely used in farms and slaughter houses may also contribute in the development of AMR. Though the direct transmission of AMR from food-animals and related environment to human is still vague and debatable, the risk should not be neglected. Therefore, combined global efforts are necessary for the proper use of antimicrobials, heavy metals and biocides in agri-food production to control the development of AMR. These collective measures will preserve the effectiveness of existing antimicrobials for future generations.
\end{abstract}

Keywords: Antimicrobial resistance, Co-selection, Heavy metal, Biocide, Dissemination, Antimicrobial resistance gene

\section{Introduction}

Antimicrobials, including antibiotics and related semi synthetic or synthetic drugs exhibit high antimicrobial potency and selective toxicity to allow their use as antiinfective agents [1]. Over the years, antimicrobials have also been used in animal husbandry and aquaculture for growth promotion, feed efficiency improvement, prophylaxis as well as in the treatment of infectious diseases. From the animal welfare perspective, the use of antimicrobials improves the general health of farm animals and the hygiene of farming environments [1]. The agricultural food industry benefits from the use of antimicrobials for food-animal production and crop protection. In United States, nearly $80 \%$ of antibiotics produced are

\footnotetext{
* Correspondence: chengguyue@mail.hzau.edu.cn

${ }^{\dagger}$ Guyue Cheng and Jianan Ning contributed equally to this work.

'MOA Laboratory for Risk Assessment of Quality and Safety of Livestock and

Poultry Products, Huazhong Agricultural University, Wuhan 430070, China

Full list of author information is available at the end of the article
}

used in animal husbandry [2]. It was estimated, that globally each kilogram of meat harvested from cattle, chickens and pigs would lead to the consumption of $45 \mathrm{mg}$, $148 \mathrm{mg}$, and $172 \mathrm{mg}$ of antimicrobials respectively, which is expected to increase by 67\% from 2010 to 2030 [3].

Anti-microbial resistance is a recognized public health concern since its emergence limits the therapeutic options available to both clinicians and veterinarians. The first economic report on the impact of AMR proposed that if nothing was done, AMR-related deaths would increase from 700,000 to 10 million annually by 2050 . It would cost trillions of USD in healthcare industry [4]. The improper use of antimicrobials for purposes other than treatment of infections has resulted in the selection for AMR in food production environments. Bacteria develop de novo resistance due to exposure to subinhibitory levels of antibiotics in their surroundings or directly acquire resistance mechanisms from other bacteria via, Horizontal Gene Transfer (HGT) [5]. 
Although widespread AMR has been mostly attributed to the selective pressure generated by overuse and misuse of antimicrobials, concerns have been raised based on recent growing evidences regarding co-selection for AMR among bacteria exposed to non-antibiotic compounds used in agri-food industry, such as biocides used as disinfectants, antiseptics and preservatives, heavy metals existing in nature and used in agricultural production [6]. The use of antimicrobials, heavy metals and biocides in food and agriculture has direct as well as indirect effects on the development of AMR in bacteria which can enter the food chain. Increasing unrest among public about antimicrobials usage in farming practices and the emergence of Multi-drug Resistant Bacteria has placed pressure on the agricultural food industry to act. A major area under scrutiny is the livestock food chain, from farms through slaughter houses and processing plants food to packaging and retail facilities [7]. This review will summarize the major factors in the selection and dissemination of food borne AMR along the food chain.

\section{Selection of AMR by using antimicrobials}

Mechanisms of AMR and pre-existence of antimicrobial resistance genes (ARGs)

Antimicrobial resistance includes two levels of resistance, the cellular level resistance and blocking of antimicrobial target and reduce entry of antimicrobials into or active efflux of antimicrobials out of the bacterial cell [2]. Reduced susceptibility of an organism to an antimicrobial may be innate (due to features of the microbe's cell envelope, energy metabolism or the presence of an alternative metabolic pathway). It is also acquired via single or multi-step mutation that affects the target site and the effective concentration of the antimicrobial within the cell, or by the acquisition of genetic element encoding a feature such as an inactivating enzyme or an alternative to the target molecule i.e. HGT of resistance determinants. Table 1 show the representative mobile ARGs which are transferable between different bacterial strains and species. The community level resistance (biofilms and persisters) is also an issue causing antimicrobial therapy difficulties [26].

Antimicrobial resistance however, did not originate as a product of agricultural antimicrobial use. Antibiotic resistance is an ancient bacterial trait, existing in soil bacteria (the soil resistome) and carried on plasmids such as serine $\beta$-lactamases, millions of years before the dawn of agriculture [27]. Recent work has uncovered resistance in ancient permafrost, isolated caves, and in human specimens preserved for hundreds of years [28]. It had been shown that gene-encoding resistance to $\beta$-lactam, Tetracycline, and Glycopeptide antibiotics was present in metagenome samples of 30,000-year-old permafrost
[29]. The gut microbiome of a pre-Columbian Andean mummy (dating of 980-1170 AD) was recently found to harbor $\beta$-lactam, Fosfomycin, Chloramphenicol, Aminoglycoside, Macrolide, Sulfa, Quinolones, Tetracycline, and Vancomycin resistance genes [30]. In a screen of sample of the culture-able microbiome of Lechuguilla Cave isolated for over 4 million years, the surface microbes were highly resistant to antimicrobials and some strains were resistant to 14 different commercially available antimicrobials including daptomycin and macrolide [31]. The results of these studies gave direct experimental evidence that AMR is ancient, and provided a glimpse into the evolutionary history of a natural environmental phenomenon.

\section{Selection of AMR in mutant selection window and sub- inhibitory concentrations}

The concentration of an antimicrobial, either in the Mutant Selection Window (MSW) or below the minimum inhibitory concentration (MIC) of a wild-type population (also called sub-inhibitory concentration or sub-MIC concentration) is important for the selection of AMR [32]. MSW is a concentration range between the lowest concentration that exerts selective pressure, often approximated by the minimal concentration that inhibits colony formation by $99 \%$ (MIC99) and the MIC of the least drugresistant mutant subpopulation, a value called the mutant prevention concentration (MPC) [33]. Drug-resistant mutant subpopulations present prior to the initiation of antimicrobial treatment are enriched and amplified when antimicrobial concentrations fall within the MSW.

Antimicrobials at sub-inhibitory concentrations (concentrations below MIC) are found in many natural environments like soil and water. Sub inhibitory concentrations are also generated as a result of antimicrobial therapy in humans and livestock (suboptimal dosing therapy, poor pharmacokinetics, usage of low-quality drugs, and a poor patient compliance) as well as administered as a feed additives to promote growth of animals [5]. In sub-MIC concentrations, the susceptible strains continue growing at a reduced growth rate, and the lowest antimicrobial concentration needed to choose for the resistant mutant over the wild type is called The Minimal Selective Concentration (MSC), from which to MIC the selection for the resistant mutants occurs [34]. Beside the pre-existed resistant mutants, de novo bacterial resistance may be promoted through sub-therapeutic antimicrobial concentrations by inducing non-specific mutagenesis resulting from stimulating the production of Reactive Oxygen Species [35].

\section{Selection of ARGs in food production system}

Antimicrobial feeding in food animals has been as a selective force in the evolution of their intestinal bacteria, particularly by increasing the prevalence and diversity of 
Table 1 Mobile antimicrobial resistance genes

\begin{tabular}{|c|c|c|c|c|c|}
\hline Antibiotic Class & $\begin{array}{l}\text { Mechanisms of } \\
\text { resistance }\end{array}$ & Gene & $\begin{array}{l}\text { Gene } \\
\text { location }\end{array}$ & Species & Reference \\
\hline \multirow[t]{6}{*}{$\beta$-lactams } & \multirow[t]{6}{*}{$\begin{array}{l}\text { Drug degradation: } \\
\beta \text {-lactamases }\end{array}$} & $\begin{array}{l}\text { Class A: } \\
\text { Serine Penicillinases: TEM, } \\
\text { SHV, CTX-M; } \\
\text { Carbapenemases: KPC, } \\
\text { IMI-2, GES }\end{array}$ & \multirow[t]{4}{*}{ Plasmid } & $\begin{array}{l}\text { Multiples species of Enterobacteriaceae, } \\
\text { Acinetobacter and Pseudomonas }\end{array}$ & \multirow[t]{6}{*}[8-10]{} \\
\hline & & $\begin{array}{l}\text { Class B (Metallo- } \beta \text {-Lactamases): } \\
\text { NDM-1, IMP, VIM, NDM-9 }\end{array}$ & & $\begin{array}{l}\text { Stenotrophomonas maltophilia and } \\
\text { Enterobacteriaceae (NDM-1), } \\
\text { Klebsiella variicola (NDM-9) }\end{array}$ & \\
\hline & & $\begin{array}{l}\text { Class C (Cephalosporinases): } \\
\text { AmpC }\end{array}$ & & Enterobacteriaceae and Pseudomonas & \\
\hline & & $\begin{array}{l}\text { Class D (oxacillinases): } \\
\text { OXA-23, OXA-48, OXA-181, } \\
\text { OXA-143, OXA-372 }\end{array}$ & & $\begin{array}{l}\text { Acinetobacter, Enterobacteriaceae, } \\
\text { Aeromonas, Citrobacter freundii }\end{array}$ & \\
\hline & & Class A: GES-1,VEB-1 & \multirow[t]{2}{*}{ Integron } & $\begin{array}{l}\text { K. pneumonia, } P \text {. aeruginosa } \\
\text { and A. baumannii }\end{array}$ & \\
\hline & & Class B: NDM-1, IMP, VIM, & & $\begin{array}{l}\text { Stenotrophomonas maltophilia, } \\
\text { Enterobacteriaceae and A. } \\
\text { baumannii (NDM-1) }\end{array}$ & \\
\hline \multirow[t]{5}{*}{ Aminoglycosides } & \multirow[t]{3}{*}{ Drug modification } & $\begin{array}{l}\text { Nucleotidyltransferases: } \\
\text { ANT(6)-la, ANT(9)-lb, } \\
\text { ANT(4')-la C, ANT(4')-Ila } \\
\text { ANT(6)-lb, ANT(4')-llb, } \\
\text { ANT(9)-la, ANT(2")-la, } \\
\text { ANT(3")-la } \\
\text { aadA31 }\end{array}$ & $\begin{array}{l}\text { Plasmid } \\
\text { Transposon } \\
\text { Plasmid, } \\
\text { transposon, } \\
\text { integrin } \\
\text { Integron }\end{array}$ & $\begin{array}{l}\text { Staphylococcus epidermidis, S. } \\
\text { aureus, E. faecium, Streptococcus } \\
\text { suis, P. aeruginosa, A. baumannii, } \\
\text { P. aeruginosa, Vibrio cholera, } \\
\text { Salmonella spp. S. enterica, E. coli, } \\
\text { Aeromonas media, Pasteurella } \\
\text { multocida, Yersinia enterocolitica, } \\
\text { C. glutamicum, B. subtilis } \\
\text { Pasteurella multocida and } \\
\text { Histophilus somni }\end{array}$ & \multirow[t]{3}{*}[11,12]{} \\
\hline & & $\begin{array}{l}\text { Phosphotransferases: } \\
\text { APH(4)-la, APH(6)-Id, } \\
\text { APH(3')-Ib, -IIla C, -Via, } \\
\text {-VIb, -VIlla, APH(2")-la, -IIla C } \\
\text { APH(6)-Ic, } \\
\text { APH(3')-la, - Ila C } \\
\text { APH(3')-Ic, APH(2")-le, } \\
\text { APH(3")-Ib }\end{array}$ & $\begin{array}{l}\text { Plasmid } \\
\text { Transposon } \\
\text { Plasmid, } \\
\text { transposon }\end{array}$ & $\begin{array}{l}\text { E. coli, S. enterica, P. aeruginosa, K. } \\
\text { pneumoniae, Salmonella spp., } \\
\text { Pseudomonas spp., V. cholerae, } \\
\text { Edwardsiella tarda, Pasteurella } \\
\text { multocida, Aeromonas bestiarum, } \\
\text { A. baumannii, S.marcescens, } \\
\text { Corynebacteriumspp., Photobacterium } \\
\text { spp., Citrobacter spp. S. aureus, } \\
\text { Enterococcus spp. E. casseliflavus }\end{array}$ & \\
\hline & & 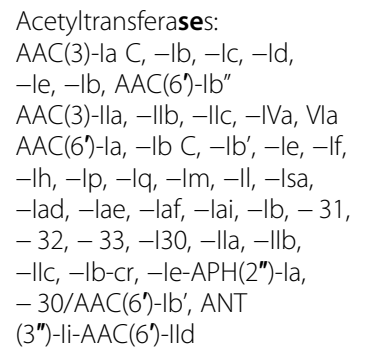 & $\begin{array}{l}\text { Integron } \\
\text { Plasmid } \\
\text { Plasmid, } \\
\text { transposon, } \\
\text { integron }\end{array}$ & $\begin{array}{l}\text { P. aeruginosa, P. fluorescens, S. } \\
\text { enterica, E. coli, E. cloacae, Salmonella } \\
\text { typhimurium, Proteus mirabilis, E. } \\
\text { faecalis, E. faecium, Streptomyces } \\
\text { albulus, C. freundii, A. baumannii, } \\
\text { S. marcescens, Actinobacillus } \\
\text { pleuropneumoniae, S. typhimurium, } \\
\text { Citrobacter freundii }\end{array}$ & \\
\hline & \multirow[t]{2}{*}{$\begin{array}{l}\text { Target modification: } \\
16 \mathrm{~S} \text { rRNA } \\
\text { methyltransferase }\end{array}$} & $\operatorname{armA}, r m t B, r m t C, r m t H$ & Plasmid & $\begin{array}{l}\text { K. pneumonia, E. coli, S. enterica, } \\
\text { P. stuartii, } \\
\text { E. aerogenes, }\end{array}$ & \multirow[t]{2}{*}{ [13] } \\
\hline & & $\begin{array}{l}\operatorname{armA}, r m t A, r m t B, r m t C, n p m A \text {, } \\
r m t D, r m t E, r m t D 2\end{array}$ & $\begin{array}{l}\text { Transposon/ } \\
\text { integron }\end{array}$ & $\begin{array}{l}\text { C. freundii, P. aerugonosa, } \\
\text { S. marcescens, P. mirabilis, E. coli, }\end{array}$ & \\
\hline \multirow[t]{3}{*}{ Quinolones } & Drug modification & Acetyltransferase: $a a c\left(6^{\prime}\right)-l b-c r$ & Plasmid & Multiple species of Enterobacteriaceae & \multirow[t]{3}{*}{ [14] } \\
\hline & Target protection & $\begin{array}{l}\text { anrA, anrB, anrs, anrC, anrD, } \\
\text { anrVC }\end{array}$ & Plasmid & $\begin{array}{l}\text { Multiple species of Enterobacteriaceae, } \\
\text { also Acinetobacter, Aeromonas, } \\
\text { Pseudomonas, and Vibrio spp. }\end{array}$ & \\
\hline & Efflux pumps & oqxAB, qepA & Plasmid & Multiples species of Enterobacteriaceae & \\
\hline Macrolides & Efflux pumps & $m e f B$ & Plasmid & E. coli & {$[15,16]$} \\
\hline
\end{tabular}


Table 1 Mobile antimicrobial resistance genes (Continued)

\begin{tabular}{|c|c|c|c|c|c|}
\hline Antibiotic Class & $\begin{array}{l}\text { Mechanisms of } \\
\text { resistance }\end{array}$ & Gene & $\begin{array}{l}\text { Gene } \\
\text { location }\end{array}$ & Species & Reference \\
\hline & & mefC & & $\begin{array}{l}\text { marine bacteria including Vibrio } \\
\text { and Photobacterium }\end{array}$ & \\
\hline & & mefl & Transposon & S. pneumoniae & \\
\hline & & mefA, mefE & $\begin{array}{l}\text { Integron } \\
\text { /transposon }\end{array}$ & Streptococcus, Staphylococci & \\
\hline & & $\operatorname{msr}(A)$ & Plasmid & Staphylococci & \\
\hline & Drug modification & $\begin{array}{l}\text { Phosphotransferase: } \\
m p h C, m p h A, m p h E\end{array}$ & Plasmid & $\begin{array}{l}\text { S. aureus, E. coli, Serratia marscescens, } \\
\text { K. pneumonia, A. baumannii, E. coli, } \\
\text { Citrobacter freundii }\end{array}$ & \\
\hline & & Esterase: ereA, ereB & Plasmid & E. coli & \\
\hline & $\begin{array}{l}\text { Target modification: } \\
\text { 23S rRNA methylase }\end{array}$ & erm & $\begin{array}{l}\text { Plasmid/ } \\
\text { transposon/ } \\
\text { integron }\end{array}$ & Multiple species & \\
\hline & $\begin{array}{l}\text { Ribosomal protection: } \\
\text { ABC-F proteins }\end{array}$ & $\operatorname{msr}(A)$ & Plasmid & staphylococci, enterococci, streptococci & \\
\hline \multirow[t]{5}{*}{ Tetracyclines } & Drug modification & $\begin{array}{l}\text { tet } X \\
\text { tet34 } \\
\text { tet37 }\end{array}$ & & $\begin{array}{l}\text { Bacteroides, Aeromonas, Pseudomonas, } \\
\text { Serratia, Vibrio }\end{array}$ & [17] \\
\hline & Ribosomal protection & $\begin{array}{l}\text { tet } M, \text { tet } S \text {, tet } T, \operatorname{tet} B(P), \text { tet } Q \text {, } \\
\text { tetW, tet32, tet } 36, \text { otrA }\end{array}$ & Transposon & \multirow{2}{*}{\multicolumn{2}{|c|}{$\begin{array}{l}\text { Acinetobacter, Afipia, Enterobacter, } \\
\text { Erysipelothrix, Escherichia, Klebsiella, } \\
\text { Lactobacillus, Lactococcus, Microbacterium, } \\
\text { Mitsuokella, Mycobacterium, Neisseria, } \\
\text { Prevotella, Porphyromonas, Ralstonia, } \\
\text { Photobacterium, Pseudomonas, Selenomonas, } \\
\text { Streptomyces, Vibrio, Megasphaera, Neisseria, } \\
\text { Lactococcus, Lactobacillus, Veillonella, } \\
\text { Actinomyces, Arcanobacterium, Bacillus, } \\
\text { Butyrivibrio, Clostridium, Megasphaera, } \\
\text { Roseburia, Staphylococcus, Bacteroides }\end{array}$}} \\
\hline & & tetO, poxtA & $\begin{array}{l}\text { Plasmid/ } \\
\text { transponson }\end{array}$ & & \\
\hline & Efflux pump & $\begin{array}{l}\text { tet } A \text {, tet } B \text { tet } C \text {, tet } D \text {, tet } E \text {, tet } G \\
\text { tet } H \text {, tet } J \text {, tet } K \text {, tet } L \text { tet } A(P) \text {, tet } V \\
\text { tet } Y \text {, tet } Z \text {, tet } 30 \text {, tet } 31 \text {, tet } 33 \text {, } \\
\text { tet } 35 \text {, tet } 38 \text {, tet } 39 \\
\text { tcr3 } \\
\text { otrB, otr } C\end{array}$ & $\begin{array}{l}\text { Plasmid/ } \\
\text { Transposon }\end{array}$ & $\begin{array}{l}\text { Acinetobacter, Haemophilus, Veillonella, } \\
\text { Acinetobacter, Brevundimonsa, Neisseria, } \\
\text { Photobacterium, Pseudomonas, Aeromonas, } \\
\text { Chlamydia, Alteromonas, Escherichia } \\
\text { Providencia, Actinobacillus, Moraxella, } \\
\text { Pasteurella, Lactobacillus, Norcardia, } \\
\text { Streptomyces, Morganella, Norcardia, } \\
\text { Salmonella, Veillonella, Corynebacterium, } \\
\text { Stenotrophomonas, Vibrio, Staphylococcu }\end{array}$ & \\
\hline & Unknown & tetU & & Staphylococci & \\
\hline \multirow[t]{6}{*}{ Lincosamides } & $\begin{array}{l}\text { Drug modification: } \\
\text { nucleotidyltransferases }\end{array}$ & $\begin{array}{l}\operatorname{In} U A \\
\operatorname{In} U B \\
\ln U C \\
\ln U E \\
\operatorname{In} U F, \operatorname{lin} G \\
\operatorname{lin} A_{N 2} \\
\ln U G\end{array}$ & $\begin{array}{l}\text { Plasmid } \\
\text { Plasmid/ } \\
\text { integron } \\
\text { Transposon } \\
\text { Transposon }\end{array}$ & $\begin{array}{l}\text { Staphylococci } \\
\text { Staphylococci, streptococci, Erysipelothrix } \\
\text { rhusiopathiae } \\
\text { S. agalactiae, Haemophilus parasuis } \\
\text { Streptococcus suis, S. aureus } \\
\text { E. coli, Salmonella enterica } \\
\text { Bacteroides } \\
\text { Enterococcus faecalis }\end{array}$ & [18-20] \\
\hline & $\begin{array}{l}\text { Target modification: } \\
23 \mathrm{~S} \text { rRNA methylase }\end{array}$ & $c f r$ & Plasmid & $\begin{array}{l}\text { Staphylococci, Bacillus spp., Enterococcus spp., } \\
\text { Macrococcus caseolyticus, Jeotgalicoccus } \\
\text { pinnipedialis, E. coli }\end{array}$ & \\
\hline & & erm & $\begin{array}{l}\text { Plasmid/ } \\
\text { transposon/ } \\
\text { integron }\end{array}$ & Multiple species & \\
\hline & $\begin{array}{l}\text { Ribosomal protection: } \\
\text { ABC-F proteins }\end{array}$ & $\begin{array}{l}\text { vga } \\
\text { Isa }\end{array}$ & $\begin{array}{l}\text { Plasmid/ } \\
\text { transposon }\end{array}$ & Staphylococci, enterococci, streptococci & \\
\hline & Efflux pump & Isa(B) & Plasmid & Staphylococci & \\
\hline & & $\operatorname{lsa}(E)$ & Integron & & \\
\hline
\end{tabular}


Table 1 Mobile antimicrobial resistance genes (Continued)

\begin{tabular}{|c|c|c|c|c|c|}
\hline Antibiotic Class & $\begin{array}{l}\text { Mechanisms of } \\
\text { resistance }\end{array}$ & Gene & $\begin{array}{l}\text { Gene } \\
\text { location }\end{array}$ & Species & Reference \\
\hline & & $\operatorname{vga}(A), \operatorname{vga}(E)$ & $\begin{array}{l}\text { Transposon/ } \\
\text { plasmid }\end{array}$ & $\begin{array}{l}\text { Staphylococci, streptococci, } \\
\text { enterococci }\end{array}$ & \\
\hline & & $\operatorname{vga}(C)$ & Plasmid & & \\
\hline & & $\operatorname{sal}(A)$ & Integron & Staphylococci & \\
\hline \multirow[t]{8}{*}{ Phenicols } & $\begin{array}{l}\text { Drug modification: } \\
\text { Acetyltransferase }\end{array}$ & $\begin{array}{l}\text { cat } A \\
\text { catB }\end{array}$ & $\begin{array}{l}\text { Plasmid/ } \\
\text { transposon } \\
\text { Integron/ } \\
\text { transposon }\end{array}$ & $\begin{array}{l}\text { Multiple species of Gram-positive } \\
\text { and Gram-negative bacteria } \\
\text { Multiple species of Gram-negative } \\
\text { bacteria }\end{array}$ & \\
\hline & $\begin{array}{l}\text { Target modification: } \\
23 S \text { rRNA methylase }\end{array}$ & $c f r$ & Plasmid & $\begin{array}{l}\text { Staphylococci, Bacillus spp., } \\
\text { Enterococcus spp., Macrococcus } \\
\text { caseolyticus, Jeotgalicoccus } \\
\text { pinnipedialis, E. coli }\end{array}$ & [21] \\
\hline & Efflux pump & optrA & Plasmid & Enterococci & {$[19,22]$} \\
\hline & & $\mathrm{cmr}, \mathrm{cmx}$ & $\begin{array}{l}\text { Plasmid/ } \\
\text { transposon }\end{array}$ & $\begin{array}{l}\text { Corynebacterium spp., } \\
\text { Rhodococcus spp. }\end{array}$ & \\
\hline & & floR & $\begin{array}{l}\text { Plasmid/ } \\
\text { integron }\end{array}$ & $\begin{array}{l}\text { E. coli, K. pneumoniae, } \\
\text { Pasteurella multocida, Pasteurella } \\
\text { trehalosi, A. pleuropneumoniae, } \\
\text { Stenothrophomonas maltophilia, } \\
\text { P. multocida }\end{array}$ & \\
\hline & & fexA & Transposon & Staphylococci & \\
\hline & & $\operatorname{fex} B$ & Plasmid & Enterococci & \\
\hline & & oqxAB & Plasmid & Multiple species of Enterobacteriaceae & \\
\hline \multirow[t]{7}{*}{ Streptogramin } & Drug modification & $\begin{array}{l}\text { Streptogramin } A \\
\text { acetyltransferase: } \\
\operatorname{vat}(A), \operatorname{vat}(B), \operatorname{vat}(C) \\
\operatorname{vat}(D), \operatorname{vat}(E), \operatorname{vat}(H)\end{array}$ & Plasmid & $\begin{array}{l}\text { Staphylococci } \\
\text { Enterococci }\end{array}$ & [19] \\
\hline & & $\begin{array}{l}\text { Streptogramin B lactone } \\
\text { hydrolase: } \\
\operatorname{vg} b(A), \operatorname{vg} b(B)\end{array}$ & Plasmid & Staphylococci & \\
\hline & $\begin{array}{l}\text { Target modification: } \\
23 S \text { rRNA methylase }\end{array}$ & streptogramin A: cfr & Plasmid & $\begin{array}{l}\text { Staphylococci, Bacillus spp., } \\
\text { Enterococcus spp., Macrococcus } \\
\text { caseolyticus, Jeotgalicoccus } \\
\text { pinnipedialis, E. coli }\end{array}$ & \\
\hline & & streptogramin B: erm & $\begin{array}{l}\text { Plasmid/ } \\
\text { transposon/ } \\
\text { intergron }\end{array}$ & Multiple species & \\
\hline & $\begin{array}{l}\text { Ribosomal protection: } \\
\text { ABC-F proteins }\end{array}$ & streptogramin B: $m s r(A)$ & Plasmid & $\begin{array}{l}\text { Staphylococci, enterococci, } \\
\text { streptococci }\end{array}$ & \\
\hline & Efflux pump & $\begin{array}{l}\text { streptogramin } A: \\
\operatorname{vga} a, \text { Isa }(A), \operatorname{sal}(A)\end{array}$ & $\begin{array}{l}\text { Plasmid/ } \\
\text { transposon/ } \\
\text { intergron }\end{array}$ & $\begin{array}{l}\text { Staphylococci, enterococci, } \\
\text { streptococci }\end{array}$ & \\
\hline & & $\begin{array}{l}\text { streptogramin } B: \\
\operatorname{msr}(A), \operatorname{msr}(C)\end{array}$ & $\begin{array}{l}\text { Plasmid/ } \\
\text { integron }\end{array}$ & & \\
\hline Polymyxin & LPS modification & $\begin{array}{l}\text { Phosphoethanolamine } \\
\text { transferase: } m c r-1,-2,-3,-4 \text {, } \\
-5,-6,-7 \text {, and }-8\end{array}$ & Plasmid & $\begin{array}{l}\text { E. coli, K. pneumonia, Salmonella, } \\
\text { Shigella sonnei, Enterobacter, } \\
\text { Cronobacter sakazakii, } \\
\text { Kluyvera ascorbata }\end{array}$ & {$[23,24]$} \\
\hline Vancomycin & Target modification & $\operatorname{van} A-G$ & $\begin{array}{l}\text { Plasmid/ } \\
\text { transposon/ } \\
\text { integron }\end{array}$ & $\begin{array}{l}\text { Staphylococci, enterococci, } \\
\text { streptococci, Oerskovia turbata, } \\
\text { Arcanobacterium haemolyticum }\end{array}$ & {$[25]$} \\
\hline
\end{tabular}

ARGs [27]. However, the association between antimicrobial use and selection of resistance determinants is not as direct as often presumed. A recent study done in
Danish pig farms demonstrated that the effect of antimicrobial exposure on the levels of seven ARGs (ermB, ermF, sulI, sulII, tetM, tetO, and tetW) was complex and 
unique for each individual gene. Several antimicrobial classes had both negative and positive correlations with the ARGs, indicating that antimicrobial exposure is not the only important determinant of the ARG levels [36]. In American swine production system, Ceftiofur is often administered to piglets at birth with males receiving a second dose at castration, and this operation may provide the selection pressure required for the dissemination of Carbapenemase-producing Enterobacteriaceae [37]. In Campylobacter jejuni isolates from beef cattle in confined feeding operations in Southern Alberta Canada, selection for resistance to fluoroquinolones was subtype dependent, whereas selection for resistance to tetracycline's was not [38]. It was shown that the development of ciprofloxacin resistance was quite different among different serovar strains, due to the different mutation frequency and ciprofloxacin accumulation level [39].

\section{Co-selection of AMR by using non-antimicrobial compounds}

Widespread AMR is mostly attributed to the selective pressure by overuse and misuse of antimicrobials. However, concerns have been raised based on growing evidences regarding co-selection of AMR among bacteria exposed to biocides which are used as disinfectants, antiseptics, preservatives and various cationic heavy metals included in animal diets as nutritional supplements, growth promoters and therapeutic agents for livestock [6]. These metals can also be spread on pastures to support crop growth and protection.

\section{Co-selection of AMR by heavy metals}

Heavy metals occur everywhere in the environment, and on occasion at high concentrations in certain settings when they are used in agriculture production for various purposes. Heavy metals can continue to exist in the environment and remain stable for prolonged periods. While most veterinary antimicrobial compounds can be metabolized and cleared from the food-producing animals within weeks or months. The bioavailability of commonly feed-used minerals (mostly inorganic) is usually quite low in animals, and the unabsorbed heavy metals are excreted as fecal material in higher concentrations than in feeds [40].

The correlation between heavy metal tolerance and AMR had already been observed several decades ago. Copper $(\mathrm{Cu})$ has been reported to be related to resistance against Ampicillin, Sulphanilamide [41], Erythromycin [42], Enrofloxacin [43], Vancomycin [44], and Glycopeptide [45]. Methicillin-resistant Staphylococcus aureus (MRSA) is often associated with Zinc $(\mathrm{Zn})$ [45-48] and $\mathrm{Cu}$ [45]. There are positive correlations between Mercury $(\mathrm{Hg})$ tolerant gene merA and transposon Tn21 [42]. sulA and sulIII were strongly correlated with levels of $\mathrm{Cu}, \mathrm{Zn}$ and $\mathrm{Hg}$ [49].
Multidrug-resistant CTX-M-(15, 9, 2) and KPC-2producing Enterobacter hormaechei and E. asburiae are found to possess a set of acquired Silver (Ag) resistance genes [50]. Other heavy metals including Nickel (Ni), Cadmium $(\mathrm{Cd})$, and Chromium $(\mathrm{Cr})$ are also reported to coselect certain AMR [42, 51-53]. A recent study showed that genes potentially conferring metal-resistance, including $\operatorname{ars} A$ (Arsenic compounds), $c a d D(\mathrm{Cd}), \operatorname{cop} B(\mathrm{Cu})$ and $c z r C$ $(\mathrm{Zn} / \mathrm{Cd})$ were frequently present in livestock associated MRSA [54]. A Chinese study even found only a weak positive correlation between ARGs and their corresponding antimicrobials, while significant positive correlations were found between some ARGs (sulA and sulIII) and typical heavy metals such as $\mathrm{Hg}, \mathrm{Cu}$, and $\mathrm{Zn}$ [49].

The molecular mechanisms for the ability of bacteria to develop heavy metal resistance are similar to those for AMR since heavy metals have known antimicrobial effects [55]. Co-selection is achieved in two ways: (1) Co-resistance, whereby selection for one gene fosters the maintenance of another resistance gene and (2) Cross-resistance, whereby one resistance gene can offer protection from multiple toxic chemicals [56]. Coresistance/Co-transfer for a heavy metal and an antimicrobial is often caused by the co-resident metal and antimicrobial- resistance genes, which can be physically localized to plasmids or chromosomes that also contain one or more ARGs $[57,58]$. For example, MRSA from livestock have been described harboring plasmids carrying resistance genes for $\mathrm{Cu}$ and $\mathrm{Cd}(\operatorname{cop} A, \operatorname{cadDX}$ and $m c o$ ) and for multiple antimicrobials including Macrolides, Lincosamides, Streptogramin B, Tetracyclines, Aminoglycosides and Trimethoprim $(\operatorname{erm}(T), \operatorname{tet}(L)$, $a a d D$ and $d f r K)$ [59]. The link between $\mathrm{Zn}$ usage in animal feeds and the occurrence of MRSA is explained by the physical presence of the $\mathrm{Zn}$ resistance gene, $c z r C$, on the methicillin resistance-encoding SCCmec element $[60,61]$. Another example of co-resistance involved a number of resistance genes such as aadA2 (streptomy$\operatorname{cin}^{\mathrm{R}}$ ), qacED1 (spectinomycin ${ }^{\mathrm{R}}$ ) and sul1 (sulfonami$\mathrm{de}^{\mathrm{R}}$ ) located to $\operatorname{Tn} 5045$ where chromate resistance genes $\operatorname{ch} B A C F$ are found [62]. A Portuguese study found in monophasic S. Typhimurium variants of human and pig origin that ARGs in this multi-drugresistant Pathovar were co-located with sil operon which encoded an efflux for $\mathrm{Cu}$ and $\mathrm{Ag}$ on the chromosome or a non-transferable plasmid [63]. A conjugation assay demonstrated co-transfer of $\operatorname{tcr} B$ and $\operatorname{erm}(B)$ genes between E. faecium and E. faecalis strains [64]. Genomic analysis of E. faecalis from $\mathrm{Cu}$-supplemented Danish pigs revealed the presence of chromosomal $\mathrm{Cu}$ insusceptibility genes, including the $\operatorname{tcr} Y A Z B$ operon and Tetracycline (tetM) and Vancomycin (vanA) resistance genes were present in one of the " $\mathrm{Cu}$-insusceptible" isolates [65]. The genetic linkage of $\mathrm{Cu}, \mathrm{Zn}$ and 
ARGs in bacteria has been comprehensively summarized in a recent review written by Keith Poole [57].

Like antimicrobials, metals are stressors that activate a variety of adaptive/protective responses in bacteria, and this can make co-regulation of metal and antimicrobial resistance resulting in cross-resistance [66]. In Gramnegative bacteria, The Membrane Stress Responsive Two Component System CpxRA which is linked to resistance against variety of cell envelope-targeting drugs [67] is also $\mathrm{Cu}$-responsive and contributes to $\mathrm{Cu}$ tolerance [68]. In the presence of $\mathrm{Zn}$, TCS CscRS in Pseudomonas aeruginosa influences the transcription of $c z c C B A$ operon encoding an RND-type efflux pump which confers resistance to $\mathrm{Zn}, \mathrm{Cd}$ and cobalt (Co), meanwhile the CscRS system also reduces the expression of porin OprD through which imipenem enters the bacteria [69]. In Listeria monocytogenes, a Multidrug efflux pump MdrL confers resistance against a range of antimicrobials, and the same transport system also works for heavy metals such as $\mathrm{Zn}, \mathrm{Co}$ and $\mathrm{Cr}$ [70]. Similarly, the Envelope Stress Response Sigma Factor RpoE activated by Polymyxin B and linked to Polymyxin B resistance in a number of Gram-negative bacteria [71] is also activated by $\mathrm{Zn}$ in E. coli and contributes to $\mathrm{Zn}$ and $\mathrm{Cu}$ tolerance [72]. $\mathrm{Cu}$ has also been shown to increase expression of the Oxidative Stress-responsive Regulatory Gene soxS that is linked to expression of the AcrAB efflux pump and multidrug resistance in E. coli [73].

Biofilms, in which bacteria are embedded in extra cellular polymeric substances, are more resistant to heavy metals than their planktonic counterparts [74]. In turn, the biofilm matrix may drive the frequency of mutation in the bacterial genomes, which is favorable for co-selection for AMR [75]. Many reports have described in several Gram-negative bacteria that $\mathrm{Cu}$ induces a Viable but Nonculturable (VNC) state, which is a stress-induced antimicrobial-resistant dormant state [76]. A Zn-linked VNC state has also been seen in Xylella Fastidiosa, and it appears to hasten the onset of the VNC state in this organism [77]. Moreover, the exposure of $E$. coli to $\mathrm{Cu}$ has been shown to increase the recovery of small colony variants, and the slow-growing variants are typically antimicrobial-resistant for a variety of bacteria [78].

Heavy metals can also facilitate the HGT. A recent study suggested that sub-inhibitory concentrations of heavy metals accelerate the horizontal transfer of plasmid-mediated ARGs in water environment by promoting conjugative transfer of genes between E. coli strains [79]. Another study showed that via $\mathrm{Cu}$ shock at 10 and $100 \mathrm{mg} / \mathrm{L}$ loading on bacteria from a drinking water bio-filter, bacterial resistance to Rifampin, Erythromycin, Kanamycin, and a few others was significantly increased. Furthermore, the relative abundance of most ARGs, particularly the mobile genetic elements (MGE) intI and transposons, were markedly enriched by at least one-fold [80].

\section{Co-selection of AMR by biocides}

Biocides can be used as antiseptics on body surfaces, as disinfectants on equipment and surfaces in many environments including farms and hospitals, as decontaminants on carcass surfaces following slaughter, and as preservatives in pharmaceuticals, cosmetics and food [81]. A possible cross-resistance between biocides and antimicrobials is still controversial. Some studies have reported that there is no cross-resistance between biocides and antimicrobials. For example, no crossresistance between Chlorhexidine and five antimicrobials was found in 130 Salmonella spp. from two Turkey farms [82]. Among 101 genetically distinct isolates of Burkholderia cepacia, no correlation was found between the susceptibility to Chlorhexidine and 10 different antimicrobials [83]. On Enterococcus faecium, low doses of Peracetic Acid, usually used as disinfectant in wastewater treatments, promoted a bacterial adaptation but without affecting the abundance of the AGRs [84].

On the other hand, several surveys have been performed on the co-selection of AMR by biocides in bacterial isolates from food-animals and aquacultures. It has been indicated that the overall exposure to Chlorhexidine Digluconate increases the risk for resistance to a variety of antimicrobials [85]. When 310 Gram-positive isolates from milking cow teats were subjected to Iodine or Chlorhexidine antisepsis, a significant association among Streptococci between reduced susceptibility to Chlorhexidine and to Ampicillin, Tetracycline and three Aminoglycoside antibiotics [86]. In 87 isolates from seafoods, moderate positive correlations were detected for the biocides Cetrimide, Hexadecylpyridinium chloride and Triclosan with the antibiotic Cefotaxime, and also for Triclosan with Chloramphenicol and Trimethoprim/ Solfamethoxazole and with the phenolic compound Thymol [87]. It was reported in E. coli $\mathrm{O} 157$ and various Salmonella serovars reductions in susceptibility to a panel of antimicrobials following stepwise training of Triclosan, Chlorhexidine and Benzalkonium chloride [88]. Exposure of veterinary field E. coli isolates to three quaternary ammonium compounds yielded elevations of MIC that were above the clinical breakpoints for Pheni$\mathrm{col}$, Tetracycline, Fluoroquinolone, $\beta$-lactams and Trimethoprim [89]. Salmonella Enteritidis surviving a short exposure to in-use concentrations of Chlorine exhibited up to eight-fold increases in MIC values for Tetracycline, Nalidixic Acid and Chloramphenicol [90], similar to those observed with stepwise training procedures.

There are more surveys and investigations that have involved hospitals or other healthcare environments about the co-selection of AMR by biocides [6]. When the aerobic microbial communities were exposed to Benzalkonium Chloride, the community-wide MIC values for Benzalkonium Chloride, Ciprofloxacin, Tetracycline 
and Penicillin G were all increased [91]. Recent data showed that exposure of vancomycin-resistant E. faecium to Chlorhexidine for only $15 \mathrm{~min}$ up-regulates the vanA-type Vancomycin resistance gene (vanHAX) and genes associated with reduced Daptomycin susceptibility (liaXYZ) [92].

It has been demonstrated a role of efflux for the coselection of AMR in some biocide training studies [93], and reduced susceptibility to biocides may follow from the development of AMR vice versa [94-96]. Under Benzalkonium Chloride exposure, the expression of two non-specific efflux pumps genes (lde and $m d r L)$ in Listeria monocytogenes isolated from pork meat processing plants was evaluated [97]. The expression of lde was dose-dependent in the case of the post cleaning and disinfection procedure strain, while the expression of $m d r L$ was inhibited under low biocidal stress (10 ppm) and enhanced in the presence of high stress $(100 \mathrm{ppm})$. In a study of biofilm formation potential and efflux pump activity, E. coli isolates from dairy equipment that had reduced susceptibility to Benzalkonium Chloride and Ciprofloxacin proved to have superior biofilm capacity, in parallel with increased efflux activity [98]. Improved biofilm capability plus efflux has also been seen in Triclosan-adapted E. coli [99]. Genetic co-occurrences suggest that plasmids provide limited opportunities for biocides and metals to promote horizontal transfer of AMR through co-selection, whereas quite large possibilities exist for indirect selection via chromosomal biocide/metal resistance genes [100].

There are a lot of theoretical and experimental evidences that certain biocides may co-select for AMR, mainly by close link of biocide resistance determinants to AMR determinants. However, there is lack of empirical data to indicate that the use of biocides drives this co-selection of AMR in the food chain [101, 102].

\section{Transfer and dissemination of AMR in food chain}

The environmental resistome comprises both the natural AMR pool and contaminant AMR pool resulting from human activities [103]. The transfer of ARG from natural reservoirs to other bacteria may be a rare and random event, contaminant ARBs and ARGs may be able to spread rapidly and widely ((e.g. New Delhi metallo-betalactamase, blaNDM-1 [104]; extended-spectrum betalactamase blaCTXM-15 [105]; MRSA [106]).

\section{Transmission of AMR from food animals to the environments}

Microbiomes encounter low-doses or sub-therapeutic levels of antimicrobial agents from all mechanistic classes in food animal production. This modern practice exerts broad effects on the gut microbiome of food animals, which is subsequently transferred to animal waste. Land application of animal manure is a common agricultural practice potentially leading to dispersal and propagation of ARGs in environmental settings. Many studies have proved that MGEs and ARGs are closely associated in their persistence in the composts under antimicrobial selection [107]. Different manure sources may influence the fate of resistome in agro-ecosystems as shown recently in a study demonstrating that application of swine and poultry manures might enrich more soil ARGs than cattle manure, and the relative abundance of ARGs had significantly positive correlations with integrase and transposase genes [108]. A study compared 864 metagenomes from humans, animals and external environments and found that water, sediments and soil generally carried low relative abundance and few varieties of known ARGs, furthermore the wastewater/ sludge was on par with the human gut, indicating that the environments with the largest relative abundance and/or diversity of ARGs were those subjected to industrial antibiotic pollution [109].

In food animals, ARBs are usually developed in animals' bodies (especially in the gastrointestinal tract) after using antibiotics. Differently, AMR in fruits, vegetables and other foods of plant origin is often due to the contamination with ARBs and ARGs along the food chain, from primary production to consumption [110]. Important sources of microbial contamination in the preharvest environment include soil, organic fertilizers and irrigation water.

Transduction is a significant mechanism of horizontal gene transfer in natural environments, which has traditionally been underestimated as compared to transformation. A study found that soil phages were the most versatile in terms of ARG carriage, and the phages from organized farms showed varied ARGs as compared to the unorganized sector [111]. Another study screened pig feces from three commercial farms for 32 clinically relevant ARG types and found that bacteriophage DNA contained $35.5 \%$ of the target ARG types and sul1, blaTEM and $e r m B$ were found in $100 \%$ of the phage DNA samples [112]. Using the ratio index of the abundance of ARGs in bacteriophages and bacteria as an estimator of bacteriophage ability to transmit ARGs, it was found that the ratio for $q n r A$ was the greatest (about $10^{-1}$ ) and differed from the most abundant bacteriophage ARG ermB, and fexA not floR had the lowest ratio value (about $10^{-6}$ ).

\section{Transmission of AMR from the environments to humans}

The antimicrobial resistome is harbored by; (i) Antimicrobial-resistant bacteria called carriers that can spread ARG in the environment, but cannot colonize or infect the human or animal body. 
(ii) Antimicrobial-resistant bacteria called vectors that can colonize and sometimes invade the human or animal body [103]. Even though carriers are not able to colonize and infect humans, their spread and proliferation in the environment would increase the abundance and diversity of ARG in vectors. Hence, it may increase the risks of transmission of ARB to humans. It should be noted that most vectors are not pathogens, because even if vectors can colonize the human body, they may lack crucial virulence genes and therefore unable to cause disease in a healthy host [103].

In searching a literature on the evidence for human exposure to extended-spectrum $\beta$-lactamase (ESBL) producing Enterobacteriaceae, MRSA, and Vancomycinresistant Enterococcus spp. in the environment, a review paper published in 2015 found that ARBs were detected in the contamination sources $(66 / 66)$ such as wastewater and manure, and no direct evidence was found for transmission to humans through the environment [113]. Although several studies performed on molecular typing of human and environmental isolates, only one obtained this level of evidence, but the direction of transmission could not be determined (environment transmitting AMR bacteria to humans or vice versa) [114].

\section{Transmission of AMR from animals to humans through food chain or close contacts}

Many pathogens of animals are zoonotic, and therefore any development of resistance in pathogens associated with food animals may spread to humans through food chain. Human infections by antibiotic-resistant pathogens such as Campylobacter spp., Salmonella spp., E. coli and $S$. aureus are increasing [2].

The impact of animal reservoirs on human health remains debatable and unclear; nonetheless, there are some examples of direct links that have been identified. In ESBL/AmpC and Carbapenemase-producing Enterobacteriaceae occurring in animals, ESBL/AmpC- or Carbapenemase-encoding genes are most often located on MGEs favoring their dissemination [115]. In most African surveys, among ESBLs, certain blaCTX-M-15-harbouring clones (ST131/B2 or ST405/D) are mainly identified in humans. But these have also been reported in livestock species from Tanzania, Nigeria or Tunisia; international trade of poultry meat seems to have contributed to the spread of other ESBL variants, such as CTX-M-14, and clones [116]. Even though exposure to animals is regarded as a risk factor, evidence for a direct transfer of ESBL/AmpC-producing bacteria from animals to humans through close contacts is limited. The extent to which food contributes to potential transmission of ESBL/AmpC producers to humans is also not well established.
For heavy metals, associations have been identified between reduced $\mathrm{Zn}$ or $\mathrm{Cu}$ susceptibility and AMR among pig Salmonella isolates, which are foodborne pathogens [6]. Co-transmission of the $\mathrm{Cu}$ efflux-associated $t c r B$ and erythromycin resistance $\operatorname{erm}(B)$ genes has been proved between a marine sediment-derived livestock species $E n$ terococcus hirae and E. faecalis in conjugation experiments. The experiments highlighted the scope for AMR selection by the marine environment through heavy metals and its possible involvement in antibioticresistant enterococcal infections [117]. Moreover, there is reasonable evidence of a co-resistance phenomenon involving $\mathrm{Cu}$, Macrolides and perhaps Vancomycin among Enterococci of pigs, whereas the relevance of this to disease-causing strains in humans remains undetermined [6].

\section{Conclusions and perspectives}

The contribution of AMR originally selected for in the agricultural sector to resistance in human pathogens is not known exactly, but is unlikely to be negligible. Since dosing regimens are less controlled in agriculture than in human health care, veterinary and environmental microbes are often exposed to sub-inhibitory concentration of antimicrobials, which is considered as a risk factor for de novo resistance, transfer of ARGs, and selection for already existing resistance [118]. Based on the present knowledge, short treatments with the highest dose that does not cause unacceptable side-effects may be optimal for achieving therapeutic goals while minimizing development of resistance. Novel approaches such as combination or alternating therapy are promising, but need to be explored further before they can be implemented in daily practice.

Co-selection of genes that confer resistance to antimicrobials, biocides, heavy metals and other chemical hazards is a potentially ecologically and clinically important phenomenon. Non-antibiotic compounds used in agrifood production, such as antibacterial biocides and heavy metals, may also contribute to the promotion of AMR through co-selection. This may occur when resistance genes to both antimicrobials and metals/biocides are co-located together in the same cell (co-resistance), or a single resistance mechanism (an efflux pump) confers resistance to both antimicrobials and biocides/ metals (cross-resistance), leading to co-selection of bacterial strains, or mobile genetic elements (MGEs) that they carry [119].

The agri-food industry is coming under pressure to reduce its usage of antimicrobial compounds. A recent study analyzing AMR and antibiotic consumption worldwide versus many potential contributing factors found that antibiotic consumption was not significantly associated with antimicrobial resistance index. This suggest 
that reduction of antibiotic consumption will not be sufficient to control AMR because the spread of resistant strains and resistance genes seems to be the dominant contributing factor [120]. Moreover, even when no antimicrobial compounds are used, certain heavy metals or biocides can maintain or even increase the bacterial resistance against certain agents [6]. Therefore, the effort of one nation to reduce its application of antimicrobial drugs in agri-food production alone will not yield the required outcome in terms of limiting consumer exposure. Resistant zoonotic agents and commensal strains carrying AMR genes reach the human population by a variety of routes, foodstuffs being only one of these [113]. Improving sanitation, increasing access to clean water, and ensuring good governance, as well as increasing public health-care expenditure and better regulating the private health sector are all necessary to reduce global antimicrobial resistance [120]. For agri-food industry, all countries must develop a code of practice to mitigate the risks to the consumer and preserve the existing valuable chemotherapeutic agents for future generations.

\section{Abbreviations}

AMR: Antimicrobial resistance; ARB: Antimicrobial-resistant bacteria; ARG: Antimicrobial resistance gene; ESBL: Extended spectrum $\beta$-lactamase; HGT: Horizontal gene transfer; MGE: Mobile genetic element; MIC: Minimum inhibitory concentration; MRSA: Methicillin-resistant Staphylococcus aureus; VNC: Viable but Nonculturable

\section{Acknowledgments}

The authors thank the National Natural Science Foundation of China and National Key R\&D Program of China for funding this study.

\section{Author contributions}

GC and ZY contributed conception and design of the study; GC, JH and BA investigated and surveyed literatures; GC wrote the first draft of the manuscript; GC, JN, SA, HH, MD, LH, and XW revised the manuscript. All authors contributed to manuscript revision, read and approved the submitted version.

\section{Funding}

This research was funded by the National Key R\&D Program of China (2017YFC1600100; 2018YFD0500300), and the National Natural Science Foundation of China (31502115).

Availability of data and materials

Not applicable.

\section{Ethics approval and consent to participate}

Not applicable.

\section{Consent for publication}

Not applicable.

\section{Competing interests}

The authors declare that they have no competing interests.

\section{Author details}

${ }^{1}$ MOA Laboratory for Risk Assessment of Quality and Safety of Livestock and Poultry Products, Huazhong Agricultural University, Wuhan 430070, China. ${ }^{2}$ National Reference Laboratory of Veterinary Drug Residues (HZAU) and MOA Key Laboratory for the Detection of Veterinary Drug Residues in Foods, Huazhong Agricultural University, Wuhan 430070, China. ${ }^{3}$ State key laboratory of Agricultural Microbiology, College of Veterinary Medicine, Huazhong Agricultural University, Wuhan 430070, China.
Received: 31 May 2019 Accepted: 9 October 2019

Published online: 21 October 2019

\section{References}

1. Hao H, Cheng G, lqbal Z, Ai X, Hussain HI, Huang L, et al. Benefits and risks of antimicrobial use in food-producing animals. Front Microbiol. 2014;5:288.

2. Lekshmi M, Ammini P, Kumar S, Varela MF. The food production environment and the development of antimicrobial resistance in human pathogens of animal origin. Microorganisms. 2017:5(1):11.

3. Van Boeckel TP, Brower C, Gilbert M, Grenfell BT, Levin SA, Robinson TP, et al. Global trends in antimicrobial use in food animals. Proc Natl Acad Sci U S A. 2015;112(18):5649-54.

4. O'Neill J. Antimicrobial resistance: tackling a crisis for the health and wealth of nations. https://www.amr-revieworg/; 2014.

5. Andersson DI, Hughes D. Microbiological effects of sublethal levels of antibiotics. Nat Rev Microbiol. 2014;12(7):465-78.

6. Wales $A D$, Davies $\mathrm{RH}$. Co-selection of resistance to antibiotics, biocides and heavy metals, and its relevance to foodborne pathogens. Antibiotics (Basel). 2015:4(4):567-604.

7. Penesyan A, Gillings M, Paulsen IT. Antibiotic discovery: combatting bacterial resistance in cells and in biofilm communities. Molecules. 2015;20(4):5286-98.

8. Bonomo RA. Beta-lactamases: a focus on current challenges. Cold Spring Harb Perspect Med. 2017;7(1):a025239.

9. Wang X, Li H, Zhao C, Chen H, Liu J, Wang Z, et al. Novel NDM-9 metallo-beta-lactamase identified from a ST107 Klebsiella pneumoniae strain isolated in China. Int J Antimicrob Agents. 2014;44(1):90-1.

10. Antonelli A, D'Andrea MM, Vaggelli G, Docquier JD, Rossolini GM. OXA-372, a novel carbapenem-hydrolysing class $D$ beta-lactamase from a Citrobacter freundii isolated from a hospital wastewater plant. J Antimicrob Chemother. 2015;70(10):2749-56

11. Ramirez MS, Tolmasky ME. Aminoglycoside modifying enzymes. Drug Resist Updat. 2010;13(6):151-71.

12. Cameron A, Klima CL, Ha R, Gruninger RJ, Zaheer R, McAllister TA. A novel aadA aminoglycoside resistance gene in bovine and porcine pathogens. mSphere. 2018;3(1):e00568-17.

13. Wachino J, Arakawa Y. Exogenously acquired $16 \mathrm{~S}$ rRNA methyltransferases found in aminoglycoside-resistant pathogenic gram-negative bacteria: an update. Drug Resist Updat. 2012;15(3):133-48.

14. Hooper DC, Jacoby GA. Topoisomerase inhibitors: fluoroquinolone mechanisms of action and resistance. Cold Spring Harb Perspect Med. 2016;6(9):a025320.

15. Fyfe C, Grossman TH, Kerstein K, Sutcliffe J. Resistance to macrolide antibiotics in public health pathogens. Cold Spring Harb Perspect Med. 2016;6(10):a025395.

16. Feßler AT, et al. Mobile macrolide resistance genes in staphylococci. Plasmid. 2018;99:2-10.

17. Roberts MC. Update on acquired tetracycline resistance genes. FEMS Microbiol Lett. 2005;245(2):195-203.

18. Feßler AT, et al. Mobile lincosamide resistance genes in staphylococci. Plasmid. 2018;99:22-31.

19. Schwarz S, Shen J, Kadlec K, Wang Y, Brenner Michael G, Fessler AT, et al. Lincosamides, Streptogramins, Phenicols, and Pleuromutilins: mode of action and mechanisms of resistance. Cold Spring Harb Perspect Med. 2016;6(11): a027037.

20. Zhu XQ, Wang XM, Li H, Shang YH, Pan YS, Wu CM, et al. Novel Inu(G) gene conferring resistance to lincomycin by nucleotidylation, located on Tn6260 from enterococcus faecalis E531. J Antimicrob Chemother. 2017;72(4):993-7.

21. Roberts MC, Schwarz S. Tetracycline and Phenicol resistance genes and mechanisms: importance for agriculture, the environment, and humans. J Environ Qual. 2016:45(2):576-92.

22. Wang $Y, L v Y$, Cai J, Schwarz S, Cui L, Hu Z, et al. A novel gene, optrA, that confers transferable resistance to oxazolidinones and phenicols and its presence in enterococcus faecalis and enterococcus faecium of human and animal origin. J Antimicrob Chemother. 2015;70(8):2182-90.

23. Poirel L, Jayol A, Nordmann P. Polymyxins: antibacterial activity, susceptibility testing, and resistance mechanisms encoded by plasmids or chromosomes. Clin Microbiol Rev. 2017;30(2):557-96.

24. Wang X, Wang Y, Zhou Y, Li J, Yin W, Wang S, et al. Emergence of a novel mobile colistin resistance gene, $\mathrm{mcr}-8$, in NDM-producing Klebsiella pneumoniae. Emerg Microbes Infect. 2018;7(1):122

25. Werner G, Strommenger B, Witte W. Acquired vancomycin resistance in clinically relevant pathogens. Future Microbiol. 2008;3(5):547-62. 
26. Cheng G, Dai M, Ahmed S, Hao H, Wang X, Yuan Z. Antimicrobial drugs in fighting against antimicrobial resistance. Front Microbiol. 2016;7:470.

27. Allen HK, Stanton TB. Altered egos: antibiotic effects on food animal microbiomes. Annu Rev Microbiol. 2014;68:297-315.

28. Perry J, Waglechner N, Wright G. The prehistory of antibiotic resistance. Cold Spring Harb Perspect Med. 2016;6(6):a025197.

29. D'Costa VM, King CE, Kalan L, Morar M, Sung WW, Schwarz C, et al. Antibiotic resistance is ancient. Nature. 2011:477(7365):457-61.

30. Santiago-Rodriguez TM, Fornaciari G, Luciani S, Dowd SE, Toranzos GA, Marota I, et al. Gut microbiome of an 11th century AD pre-Columbian Andean mummy. PLoS One. 2015;10(9):e0138135.

31. Bhullar K, Waglechner N, Pawlowski A, Koteva K, Banks ED, Johnston MD, et al. Antibiotic resistance is prevalent in an isolated cave microbiome. PLoS One. 2012;7(4):e34953.

32. Li J, Xie S, Ahmed S, Wang F, Gu Y, Zhang C, et al. Antimicrobial activity and resistance: influencing factors. Front Pharmacol. 2017;8:364.

33. Drlica K, Zhao X. Mutant selection window hypothesis updated. Clin Infect Dis. 2007:44(5):681-8.

34. Gullberg E, Cao S, Berg OG, Ilback C, Sandegren L, Hughes D, et al. Selection of resistant bacteria at very low antibiotic concentrations. PLoS Pathog. 2011;7(7):e1002158.

35. Kohanski MA, DePristo MA, Collins JJ. Sublethal antibiotic treatment leads to multidrug resistance via radical-induced mutagenesis. Mol Cell. 2010;37(3):311-20.

36. Birkegard AC, Halasa T, Graesboll K, Clasen J, Folkesson A, Toft N. Association between selected antimicrobial resistance genes and antimicrobial exposure in Danish pig farms. Sci Rep. 2017;7(1):9683.

37. Mollenkopf DF, Mathys DA, Feicht SM, Stull JW, Bowman AS, Daniels JB, et al. Maintenance of Carbapenemase-producing Enterobacteriaceae in a farrow-tofinish swine production system. Foodborne Pathog Dis. 2018;15(6):372-6.

38. Webb AL, Selinger LB, Taboada EN, Inglis GD. Subtype-specific selection for resistance to fluoroquinolones but not to Tetracyclines is evident in campylobacter jejuni isolates from beef cattle in confined feeding operations in southern Alberta, Canada. Appl Environ Microbiol. 2018;84(7):e02713-17.

39. Zhang WH, Zhang CZ, Liu ZJ, Gu XX, Li W, Yang L, et al. In vitro development of ciprofloxacin resistance of salmonella enterica Serovars typhimurium, Enteritidis, and Indiana isolates from food animals. Microb Drug Resist. 2017;23(6):687-94.

40. Medardus JJ, Molla BZ, Nicol M, Morrow WM, Rajala-Schultz PJ, Kazwala R, et al. In-feed use of heavy metal micronutrients in U.S. swine production systems and its role in persistence of multidrug-resistant salmonellae. Appl Environ Microbiol. 2014;80(7):2317-25.

41. Berg J, Tom-Petersen A, Nybroe O. Copper amendment of agricultural soil selects for bacterial antibiotic resistance in the field. Lett Appl Microbiol. 2005;40(2):146-51.

42. Chenia HY, Jacobs A. Antimicrobial resistance, heavy metal resistance and integron content in bacteria isolated from a south African tilapia aquaculture system. Dis Aquat Organ. 2017;126(3):199-209.

43. Zou X, Weng M, Ji X, Guo R, Zheng W, Yao W. Comparison of antibiotic resistance and copper tolerance of enterococcus spp. and lactobacillus spp. isolated from piglets before and after weaning. J Microbiol. 2017;55(9):703-10.

44. Hasman H, Kempf I, Chidaine B, Cariolet R, Ersboll AK, Houe H, et al. Copper resistance in enterococcus faecium, mediated by the $t c r B$ gene, is selected by supplementation of pig feed with copper sulfate. Appl Environ Microbiol. 2006;72(9):5784-9.

45. Yazdankhah S, Rudi K, Bernhoft A. Zinc and copper in animal feed development of resistance and co-resistance to antimicrobial agents in bacteria of animal origin. Microb Ecol Health Dis. 2014;25(1):25862.

46. Amachawadi RG, Scott HM, Nitikanchana S, Vinasco J, Tokach MD, Dritz SS, et al. Nasal carriage of mecA-positive methicillin-resistant Staphylococcus aureus in pigs exhibits dose-response to zinc supplementation. Foodborne Pathog Dis. 2015;12(2):159-63.

47. Slifierz MJ, Friendship R, Weese JS. Zinc oxide therapy increases prevalence and persistence of methicillin-resistant Staphylococcus aureus in pigs: a randomized controlled trial. Zoonoses Public Health. 2015;62(4):301-8.

48. Cavaco LM, Hasman H, Aarestrup FM. Zinc resistance of Staphylococcus aureus of animal origin is strongly associated with methicillin resistance. Vet Microbiol. 2011;150(3-4):344-8.

49. Ji X, Shen $Q$, Liu F, Ma J, Xu G, Wang Y, et al. Antibiotic resistance gene abundances associated with antibiotics and heavy metals in animal manures and agricultural soils adjacent to feedlots in Shanghai; China. J Hazard Mater. 2012;235-236:178-85.
50. Andrade LN, Siqueira TES, Martinez R, Darini ALC. Multidrug-resistant CTX-M$(15,9,2)$ - and KPC-2-producing Enterobacter hormaechei and Enterobacter asburiae isolates possessed a set of acquired heavy metal tolerance genes including a chromosomal sil operon (for acquired silver resistance). Front Microbiol. 2018;9:539.

51. Vignaroli C, Pasquaroli S, Citterio B, Di Cesare A, Mangiaterra G, Fattorini D, et al. Antibiotic and heavy metal resistance in enterococci from coastal marine sediment. Environ Pollut. 2018;237:406-13.

52. Stepanauskas R, Glenn TC, Jagoe CH, Tuckfield RC, Lindell AH, King CJ, et al. Coselection for microbial resistance to metals and antibiotics in freshwater microcosms. Environ Microbiol. 2006;8(9):1510-4.

53. Knapp CW, McCluskey SM, Singh BK, Campbell CD, Hudson G, Graham DW. Antibiotic resistance gene abundances correlate with metal and geochemical conditions in archived Scottish soils. PLoS One. 2011;6(11):e27300.

54. Argudin MA, Lauzat B, Kraushaar B, Alba P, Agerso Y, Cavaco L, et al. Heavy metal and disinfectant resistance genes among livestock-associated methicillin-resistant Staphylococcus aureus isolates. Vet Microbiol. 2016;191:88-95.

55. Grass G, Rensing C, Solioz M. Metallic copper as an antimicrobial surface. Appl Environ Microbiol. 2011;77(5):1541-7.

56. Singer AC, Shaw $H$, Rhodes $V$, Hart A. Review of antimicrobial resistance in the environment and its relevance to environmental regulators. Front Microbiol. 2016;7:1728

57. Poole K. At the nexus of antibiotics and metals: the impact of $\mathrm{Cu}$ and $\mathrm{Zn}$ on antibiotic activity and resistance. Trends Microbiol. 2017;25(10):820-32.

58. Yu Z, Gunn L, Wall P, Fanning S. Antimicrobial resistance and its association with tolerance to heavy metals in agriculture production. Food Microbiol. 2017;64:23-32.

59. Gomez-Sanz E, Kadlec K, Fessler AT, Zarazaga M, Torres C, Schwarz S. Novel erm(T)-carrying multiresistance plasmids from porcine and human isolates of methicillin-resistant Staphylococcus aureus ST398 that also harbor cadmium and copper resistance determinants. Antimicrob Agents Chemother. 2013;57(7):3275-82.

60. Cavaco LM, Hasman H, Stegger M, Andersen PS, Skov R, Fluit AC, et al. Cloning and occurrence of czrC, a gene conferring cadmium and zinc resistance in methicillin-resistant Staphylococcus aureus CC398 isolates. Antimicrob Agents Chemother. 2010;54(9):3605-8.

61. Aarestrup FM, Cavaco L, Hasman H. Decreased susceptibility to zinc chloride is associated with methicillin resistant Staphylococcus aureus CC398 in Danish swine. Vet Microbiol. 2010;142(3-4):455-7.

62. Petrova M, Gorlenko Z, Mindlin S. Tn5045, a novel integron-containing antibiotic and chromate resistance transposon isolated from a permafrost bacterium. Res Microbiol. 2011;162(3):337-45.

63. Mourao J, Novais C, Machado J, Peixe L, Antunes P. Metal tolerance in emerging clinically relevant multidrug-resistant salmonella enterica serotype 4,[5],12:i:clones circulating in Europe. Int J Antimicrob Agents. 2015;45(6):610-6.

64. Amachawadi RG, Shelton NW, Shi X, Vinasco J, Dritz SS, Tokach MD, et al. Selection of fecal enterococci exhibiting tcrB-mediated copper resistance in pigs fed diets supplemented with copper. Appl Environ Microbiol. 2011; 77(16):5597-603.

65. Zhang S, Wang D, Wang $Y$, Hasman $H$, Aarestrup FM, Alwathnani HA, et al. Genome sequences of copper resistant and sensitive enterococcus faecalis strains isolated from copper-fed pigs in Denmark. Stand Genomic Sci. 2015;10:35.

66. Poole K. Stress responses as determinants of antimicrobial resistance in gram-negative bacteria. Trends Microbiol. 2012;20(5):227-34.

67. Audrain B, Ferrieres L, Zairi A, Soubigou G, Dobson C, Coppee JY, et al. Induction of the Cpx envelope stress pathway contributes to Escherichia coli tolerance to antimicrobial peptides. Appl Environ Microbiol. 2013;79(24):7770-9.

68. Yamamoto K, Ishihama A. Characterization of copper-inducible promoters regulated by CpxA/CpxR in Escherichia coli. Biosci Biotechnol Biochem. 2006;70(7):1688-95.

69. Caille O, Rossier C, Perron K. A copper-activated two-component system interacts with zinc and imipenem resistance in Pseudomonas aeruginosa. J Bacteriol. 2007;189(13):4561-8.

70. Mata MT, Baquero F, Perez-Diaz JC. A multidrug efflux transporter in listeria monocytogenes. FEMS Microbiol Lett. 2000;187(2):185-8.

71. Haines-Menges $B$, Whitaker WB, Boyd EF. Alternative sigma factor RpoE is important for Vibrio parahaemolyticus cell envelope stress response and intestinal colonization. Infect Immun. 2014;82(9):3667-77.

72. Egler M, Grosse C, Grass G, Nies DH. Role of the extracytoplasmic function protein family sigma factor RpoE in metal resistance of Escherichia coli. J Bacteriol. 2005;187(7):2297-307. 
73. Harrison JJ, Tremaroli V, Stan MA, Chan CS, Vacchi-Suzzi C, Heyne BJ, et al. Chromosomal antioxidant genes have metal ion-specific roles as determinants of bacterial metal tolerance. Environ Microbiol. 2009;11(10): 2491-509.

74. Harrison JJ, Ceri H, Stremick CA, Turner RJ. Biofilm susceptibility to metal toxicity. Environ Microbiol. 2004;6(12):1220-7.

75. Baker J, Sitthisak S, Sengupta M, Johnson M, Jayaswal RK, Morrissey JA. Copper stress induces a global stress response in Staphylococcus aureus and represses sae and agr expression and biofilm formation. Appl Environ Microbiol. 2010;76(1):150-60.

76. Ayrapetyan M, Williams TC, Oliver JD. Bridging the gap between viable but non-culturable and antibiotic persistent bacteria. Trends Microbiol. 2015; 23(1):7-13.

77. Navarrete F, De La Fuente L. Response of Xylella fastidiosa to zinc: decreased culturability, increased exopolysaccharide production, and formation of resilient biofilms under flow conditions. Appl Environ Microbiol. 2014;80(3):1097-107.

78. Wei Q, Tarighi S, Dotsch A, Haussler S, Musken M, Wright VJ, et al. Phenotypic and genome-wide analysis of an antibiotic-resistant small colony variant (SCV) of Pseudomonas aeruginosa. PLoS One. 2011;6(12):e29276.

79. Zhang Y, Gu AZ, Cen T, Li X, He M, Li D, et al. Sub-inhibitory concentrations of heavy metals facilitate the horizontal transfer of plasmid-mediated antibiotic resistance genes in water environment. Environ Pollut. 2018;237:74-82.

80. Zhang M, Chen L, Ye C, Yu X. Co-selection of antibiotic resistance via copper shock loading on bacteria from a drinking water bio-filter. Environ Pollut. 2018;233:132-41.

81. SCENIHR. Assessment of the antibiotic resistance effects of biocides. Brussels: Scientific Committee on Emerging and Newly Identified Health Risks, European Commission; 2009. p. 1-87.

82. Beier RC, Anderson PN, Hume ME, Poole TL, Duke SE, Crippen TL, et al. Characterization of salmonella enterica isolates from turkeys in commercial processing plants for resistance to antibiotics, disinfectants, and a growth promoter. Foodborne Pathog Dis. 2011;8(5):593-600.

83. Rose $H$, Baldwin A, Dowson CG, Mahenthiralingam E. Biocide susceptibility of the Burkholderia cepacia complex. J Antimicrob Chemother. 2009;63(3):502-10

84. Turolla A, Sabatino R, Fontaneto D, Eckert EM, Colinas N, Corno G, et al. Defence strategies and antibiotic resistance gene abundance in enterococci under stress by exposure to low doses of peracetic acid. Chemosphere. 2017; 185:480-8

85. Kampf G. Acquired resistance to chlorhexidine - is it time to establish an 'antiseptic stewardship' initiative? J Hosp Infect. 2016;94(3):213-27.

86. Martin $\mathrm{H}$, Maris $P$. Antiseptic and antibiotic resistance of 310 gram-positive strains isolated from udders after use of post-milking teat germicides. Vet Res. 1995;26(1):43-56.

87. Romero JL, Grande Burgos MJ, Perez-Pulido R, Galvez A, Lucas R. Resistance to antibiotics, biocides, preservatives and metals in bacteria isolated from Seafoods: co-selection of strains resistant or tolerant to different classes of compounds. Front Microbiol. 2017;8:1650.

88. Braoudaki M, Hilton AC. Adaptive resistance to biocides in salmonella enterica and Escherichia coli 0157 and cross-resistance to antimicrobial agents. J Clin Microbiol. 2004;42(1):73-8

89. Soumet C, Fourreau E, Legrandois P, Maris P. Resistance to phenicol compounds following adaptation to quaternary ammonium compounds in Escherichia coli. Vet Microbiol. 2012;158(1-2):147-52.

90. Potenski CJ, Gandhi M, Matthews KR. Exposure of salmonella Enteritidis to chlorine or food preservatives decreases [corrected] susceptibility to antibiotics. FEMS Microbiol Lett. 2003;220(2):181-6.

91. Tandukar M, Oh S, Tezel U, Konstantinidis KT, Pavlostathis SG. Long-term exposure to benzalkonium chloride disinfectants results in change of microbial community structure and increased antimicrobial resistance. Environ Sci Technol. 2013;47(17):9730-8.

92. Bhardwaj P, Ziegler E, Palmer KL. Chlorhexidine induces VanA-type vancomycin resistance genes in enterococci. Antimicrob Agents Chemother. 2016;60(4):2209-21.

93. Fuentes MAF, Morente EO, Abriouel H, Pulido RP, Galvez A. Antimicrobial resistance determinants in antibiotic and biocide-resistant gram-negative bacteria from organic foods. Food Control. 2014;37:9-14.

94. Buffet-Bataillon S, Le Jeune A, Le Gall-David S, Bonnaure-Mallet M, JolivetGougeon A. Molecular mechanisms of higher MICs of antibiotics and quaternary ammonium compounds for Escherichia coli isolated from bacteraemia. J Antimicrob Chemother. 2012;67(12):2837-42.
95. Buffet-Bataillon S, Tattevin P, Bonnaure-Mallet M, Jolivet-Gougeon A Emergence of resistance to antibacterial agents: the role of quaternary ammonium compounds--a critical review. Int J Antimicrob Agents. 2012; 39(5):381-9.

96. Ortega Morente E, Fernandez-Fuentes MA, Grande Burgos MJ, Abriouel H, Perez Pulido R, Galvez A. Biocide tolerance in bacteria. Int J Food Microbiol. 2013;162(1):13-25.

97. Conficoni D, Losasso C, Cortini E, Di Cesare A, Cibin V, Giaccone V, et al. Resistance to biocides in listeria monocytogenes collected in meatprocessing environments. Front Microbiol. 2016;7:1627.

98. Pagedar A, Singh J, Batish VK. Adaptation to benzalkonium chloride and ciprofloxacin affects biofilm formation potential, efflux pump and haemolysin activity of Escherichia coli of dairy origin. J Dairy Res. 2012;79(4):383-9.

99. Sheridan A, Lenahan M, Condell O, Bonilla-Santiago R, Sergeant K, Renaut J, et al. Proteomic and phenotypic analysis of triclosan tolerant verocytotoxigenic Escherichia coli O157:H19. J Proteomics. 2013;80:78-90.

100. Pal C, Bengtsson-Palme J, Kristiansson E, Larsson DG. Co-occurrence of resistance genes to antibiotics, biocides and metals reveals novel insights into their co-selection potential. BMC Genomics. 2015;16:964.

101. Hardy K, Sunnucks K, Gil H, Shabir S, Trampari E, Hawkey P, et al. Increased usage of antiseptics is associated with reduced susceptibility in clinical isolates of Staphylococcus aureus. MBio. 2018;9(3):e00894-18.

102. Bas S, Kramer M, Stopar D. Biofilm surface density determines biocide effectiveness. Front Microbiol. 2017;8:2443.

103. Manaia CM. Assessing the risk of antibiotic resistance transmission from the environment to humans: non-direct proportionality between abundance and risk. Trends Microbiol. 2017;25(3):173-81.

104. Walsh TR, Weeks J, Livermore DM, Toleman MA. Dissemination of NDM-1 positive bacteria in the New Delhi environment and its implications for human health: an environmental point prevalence study. Lancet Infect Dis. 2011;11(5):355-62.

105. Nicolas-Chanoine MH, Blanco J, Leflon-Guibout V, Demarty R, Alonso MP, Canica MM, et al. Intercontinental emergence of Escherichia coli clone 025 : H4-ST131 producing CTX-M-15. J Antimicrob Chemother. 2008;61(2):273-81.

106. Rao Q, Shang W, Hu X, Rao X. Staphylococcus aureus ST121: a globally disseminated hypervirulent clone. J Med Microbiol. 2015;64(12):1462-73.

107. Xie WY, Yang XP, Li Q, Wu LH, Shen QR, Zhao FJ. Changes in antibiotic concentrations and antibiotic resistome during commercial composting of animal manures. Environ Pollut. 2016;219:182-90.

108. Zhang YJ, Hu HW, Gou M, Wang JT, Chen D, He JZ. Temporal succession of soil antibiotic resistance genes following application of swine, cattle and poultry manures spiked with or without antibiotics. Environ Pollut. 2017; 231(Pt 2):1621-32.

109. Pal C, Bengtsson-Palme J, Kristiansson E, Larsson DG. The structure and diversity of human, animal and environmental resistomes. Microbiome. 2016;4(1):54

110. WHO. Joint FAO/WHO expert meeting on foodborne antimicrobial resistance: role of the environment, crops and biocides. http://wwww.hoint/ foodsafety/areas_work/antimicrobial-resistance/FAO_WHO_AMR_Summary_ Report_June2018pdf?ua=1; 2018.

111. Anand T, Bera BC, Vaid RK, Barua S, Riyesh T, Virmani N, et al. Abundance of antibiotic resistance genes in environmental bacteriophages. J Gen Virol. 2016;97(12):3458-66

112. Wang M, Liu $P$, Zhou Q, Tao W, Sun Y, Zeng Z. Estimating the contribution of bacteriophage to the dissemination of antibiotic resistance genes in pig feces. Environ Pollut. 2018;238:291-8.

113. Huijbers PM, Blaak H, de Jong MC, Graat EA, Vandenbroucke-Grauls CM, de Roda Husman AM. Role of the environment in the transmission of antimicrobial resistance to humans: a review. Environ Sci Technol. 2015; 49(20):11993-2004.

114. Hower S, Phillips MC, Brodsky M, Dameron A, Tamargo MA, Salazar NC, et al. Clonally related methicillin-resistant Staphylococcus aureus isolated from shortfinned pilot whales (Globicephala macrorhynchus), human volunteers, and a bayfront cetacean rehabilitation facility. Microb Ecol. 2013;65(4):1024-38.

115. Madec JY, Haenni M, Nordmann P, Poirel L. Extended-spectrum betalactamase/AmpC- and carbapenemase-producing Enterobacteriaceae in animals: a threat for humans? Clin Microbiol Infect. 2017;23(11):826-33.

116. Alonso CA, Zarazaga M, Ben Sallem R, Jouini A, Ben Slama K, Torres C. Antibiotic resistance in Escherichia coli in husbandry animals: the African perspective. Lett Appl Microbiol. 2017;64(5):318-34.

117. Pasquaroli S, Di Cesare A, Vignaroli C, Conti G, Citterio B, Biavasco F. Erythromycin- and copper-resistant enterococcus hirae from marine 
sediment and co-transfer of erm(B) and tcrB to human enterococcus faecalis. Diagn Microbiol Infect Dis. 2014;80(1):26-8.

118. Ter Kuile BH, Kraupner N, Brul S. The risk of low concentrations of antibiotics in agriculture for resistance in human health care. FEMS Microbiol Lett. 2016;363(19). https://doi.org/10.1093/femsle/fnw210.

119. Pal C, Asiani K, Arya S, Rensing C, Stekel DJ, Larsson DGJ, et al. Metal resistance and its association with antibiotic resistance. Adv Microb Physiol. 2017;70:261-313.

120. Collignon P, Beggs JJ, Walsh TR, Gandra S, Laxminarayan R. Anthropological and socioeconomic factors contributing to global antimicrobial resistance: a univariate and multivariable analysis. Lancet Planet Health. 2018;2(9):e398-405.

\section{Publisher's Note}

Springer Nature remains neutral with regard to jurisdictional claims in published maps and institutional affiliations.

Ready to submit your research? Choose BMC and benefit from:

- fast, convenient online submission

- thorough peer review by experienced researchers in your field

- rapid publication on acceptance

- support for research data, including large and complex data types

- gold Open Access which fosters wider collaboration and increased citations

- maximum visibility for your research: over $100 \mathrm{M}$ website views per year

At BMC, research is always in progress.

Learn more biomedcentral.com/submissions 